\title{
Research on the Relationship of Innovation Capability and Operating Performance Based on Moderation of Openness
}

\author{
Lu Li, Zhuo Zhang, Min Xu \\ College of Economics and Management, Nanjing University of Aeronautics and Astronautics, Nanjing, China \\ Email: 15250953791@163.com
}

Received 11 December 2015; accepted 23 February 2016; published 26 February 2016

Copyright (C) 2016 by authors and Scientific Research Publishing Inc.

This work is licensed under the Creative Commons Attribution International License (CC BY). http://creativecommons.org/licenses/by/4.0/

c. (i) Open Access

\begin{abstract}
In current research on open innovation, the impact of innovative openness on the effect of innovation capability on corporate operating performance has been ignored. This paper uses hierarchical linear regression model with financial data of 137 listed enterprises in Chinese Stock Exchanges to study the moderate effect of openness on relationship of innovation capability and operating performance. The result shows that the internal innovation capability and absorption capability can significantly affect the operating performance, but the effect of technology acquisition and diffusion capability is remarkable only under the moderation of openness. Meanwhile, innovative openness negatively impacts the effect of internal innovation capability on the operating performance, and positively impacts the effect of absorptive ability. Finally, this paper provides some suggestions for helping enterprise's implementation of open innovation strategy based on their own capabilities.
\end{abstract}

\section{Keywords}

Open Innovation, Openness, Innovation Capability, Operating Performance

\section{Introduction}

Today innovation is the key to maintain the competitiveness and market position of enterprises. With the rapid development of science and technology, more and more enterprises choose to increase investment in R\&D and transform innovation mode at the same time, paying attention to the utilization of external resources and knowledge to maintain their own competitiveness in the international market [1]. It is not only the inevitable reaction to the intensifying globalization trend, but also the natural product of increasingly fierce competition in the 
market [2].

Chesbrough proposed the concept of open innovation in 2003, defined it as "the process of the active use of internal and external resources and knowledge to achieve the maximum of corporate interests "[3]. Open innovation(OI), which is also known as open mind and innovation, mainly improves the performance of innovation through the acquisition of market information resources and technology resources, to make up for the lack of internal innovation resources [4]. The concept of OI has caused wide attention of academia and industry since it has been put forward. Most scholars agree that whether the benefits of OI can make up for the cost depends on whether the enterprise chooses appropriate open strategy according to its actual situation [5]. However, some scholars believe that OI is a risk for many firms and the blind opening can't make the maximization of the interests. In the practice of OI, how to choose the right way is not only a classical technology and economic problem, but also a strategy problem for enterprises based on their own capability.

Nevertheless, many questions about OI have not been reached to an universal agreement, such as how the OI mechanisms affect the performance and which open strategy is suitable for different types of firms [6]. Ye and Yesil note that performance is affected by capability through openness. Therefore, the degree of openness is often used as the dependent variable and innovation capability is used as a mediator or moderator variable to construct the model of research [2] [7]. However, as noted by Yun Jiang, the openness and innovation capability have an interactive effect on performance [8], or a parallel relationship studied by Ren Ailian. As a consequence, openness and innovation ability are both used as independent variables to build the relationship model [9]. The logic dilemma is that the fundamental driving force of performance is capability, rather than the virtual concept of innovation openness.

To address this question, we introduce the openness as a moderating variable into the study on the relationship between innovation capability and operating performance to explain the relationship. Then, this paper will put forward the selection method of open innovation strategy based on enterprise's situation.

\section{Literature Review and Research Hypotheses}

\subsection{Innovation Capability and Operating Performance}

Innovation capability is defined as comprehensive characteristics supporting enterprises to achieve their innovative strategies by Burgelman [10]. In the open environment, the "comprehensive" of innovation capability breaks through the boundary of the enterprise, so it also includes the external technological innovation capability [3]. Subsequently, the scholars have carried on the concrete classification of the technological innovation ability. Referring to these research conclusions, the innovation capability is divided into internal innovation capability, technology acquisition and diffusion capability and absorptive capability in this paper.

Internal innovation capability refers to the capability that transforming the internal innovation input into output. The general empirical research results show that the internal innovation capability and performance are positively related and affected by other factors. According to the research of the pharmaceutical industry by Hagedoom, the internal R\&D is the key to decide whether the enterprise can benefit from the external spillover or not [11]. The research by Wei Yingchun also found that human capital and other internal factors have a significantly positive impact on the international competitiveness of Chinese manufacturing industry [12]. He Jianhong noted that the internal technological capability and innovation strategy of enterprises both have a significant impact on the innovation performance through empirical research [13]. Furthermore, the linear model of innovation capability of high tech enterprises which has a positive impact on operating performance was confirmed by Li Qianwen [14].

This paper suggests that the reasons why innovation capability plays an important role on the performance of enterprises are as follows: firstly, enterprise competence theory believes that accumulation of internal capabilities and resources in enterprises is the sources of core capabilities, and the key to maintain sustainable competitive advantage. Secondly, internal innovation capability is a bridge connecting resources and performance, the classic model of "resources - capacity-performance" shows that the capability of transforming innovation resources into innovation output is very important to final achievement [15]. Finally, the internal innovation capability of enterprises can bring improvements on products, process or management, then reduce the cost, improve labor productivity, and create a market, thus improve business performance ultimately [16]. Based on the above analysis, this paper puts forward the following hypothesis: 
H1: Internal innovation capability is positively associated with operating performance.

Technology acquisition refers to the access to external technology and resources; technology diffusion refers to spillover of internal knowledge and technology. There are some disputes on the influence of technology acquisition and diffusion capacity in the academic circle. Tsai's research showed that the external technology acquisition capability has no significant effect on enterprise performance [17]. Wei Long found that, due to the existence of many obstacles in enterprises, such as financing, property rights, there is a certain negative impact on the technical output in the study of small and medium enterprises in China [18]. From a overall perspective, these scholars believe that the technology acquisition and diffusion capacity is not important or only have an indirect impact on enterprise performance. But some researchers find economic benefits can be brought by the model of introduction and imitation for Chinese enterprises, and the external technology acquisition and internal R\&D both have a significant positive effect on enterprise performance through empirical work [19]. Through the empirical findings, Janeiro noted that the leader of the markets is more likely to achieve better performance as a result of a stronger obtaining capability in the flow of resources [20]. Abdul-Hadi found that due to a wider range of resources, global enterprises are more favorable than the enterprises in a single market under the open environment [21]. In the study of cluster effect in China's new energy auto industry, Sui Mengqing believed that technology diffusion can bring scale performance, derived performance and economic performance. Therefore, enterprises with stronger diffusion capability in industrial clusters capture more benefits [22].

Based on the above reviews, this paper suggests that technology acquisition and diffusion capability shows the following important influence on the enterprise in the open environment: firstly, the acquisition of external technology can provide complementary and different knowledge and resources for the enterprise [23], and greatly reduce the risk of innovation [24]; secondly, technology diffusion can not only promote the level of knowledge sharing and improve the enterprise's embedness in network environment [25], but also expand the brand influence. Therefore, this paper puts forward the following hypothesis:

H2: Technology acquisition and diffusion capability is positively associated with operating performance.

With regard to the concept of absorptive capacity, many scholars made the corresponding adjustment according to the needs of their own researches, but the view that absorptive capacity is the critical link between external and internal knowledge resources is generally accepted, in other word, it is the capability of identifying, digesting, transforming and applying external knowledge [26]. The phenomena that the better ability of knowledge application, the better innovation performance the enterprise can achieve, is noted by Schuhmacher through some living examples [27]. What's more, empirical studies pointed out that enterprise's learning capability and absorptive capacity is positively related to open innovation performance by Ren Ailian [28]. Hong Ruyan pointed out that the key for China's car industry to be out of the two extreme in global manufacturing network, such as "lock in effect" and "marginalized", is actually to enhance the absorption capacity [29].

This paper suggests that the importance of absorptive capacity is mainly embodied in three aspects: the first one is to help enterprises to identify new external knowledge and understand the value of new external knowledge; the second one is to transform new knowledge obtained and digest it into the internal innovation system; the third one is to promote the enterprise to apply the digested and absorbed knowledge to innovation. Based on the above analysis, this paper puts forward the following hypothesis:

H3: Absorptive capacity is positively associated with operating performance.

\subsection{The Moderation of Openness}

In the process of open innovation, it does not necessarily bring about the equal economic benefits if the enterprise is only concerned with enhancing the capability or increasing investment. In fact, although some enterprises really achieve the benefits through open innovation, at the same time, there are a lot of enterprises is in a dilemma for it is difficult to use external knowledge to create profit, even fall into a competency-based and invest-based trap which is called "introduction-backward-reintroduction". Ye believed that the loss of intellectual property and the increase of management costs represent the negative effects of knowledge sharing [2]. Empirical studies in the past decades have also confirmed this point. Tim pointed out that the binding relationship in innovation network has a certain disputation [30]. Kim and Park found that not all of the open innovation activities of SMEs in foreign countries have a positive impact on innovation output [31]. Studies on SMEs in China have similar conclusions that small side effects will arise when enterprises cooperates with competitors and scientific research institutes [9]. Rosenbusch noted that internal innovation projects can lead to better corporate 
performance than those with external partners, so focusing on external cooperative innovation projects can't improve the performance of the enterprise. He also pointed out that the relationship between innovation and performance depends on plenty of factors, such as the enterprise's age, innovation model and cultural background, etc. [32]. Through the study of India chemical enterprises, Kafouros found that the introduction of knowledge from the domestic market has side effects on the internal innovation [33].

In this paper, we suggest that excessive openness may consume the resources originally used for internal innovation and improvement of openness will increase the risk of leaking internal innovation. Therefore, the following hypothesis is put forward in this paper:

H4: Openness is negatively associated with the relationship of internal innovation capability and operating performance.

The increase of the external knowledge's quantity and complexity may result in the difficulty and risk of absorption and transformation, so the increase of openness will require stronger absorption capacity. Westergren believed that open innovation requires a certain cost and pointed out that lack of appropriate absorptive capacity will result in a waste of resources [34]. Other researchers, such as Li Zhen, Yang Hongtao, proved that the absorptive capacity has a positive impact on innovation performance through external knowledge acquisition and integration by the empirical research on small and medium technology-based enterprises [35]. In addition, the importance of absorptive capacity in dealing with the external environment changes and improving the innovation performance in the open environment is confirmed due to the constant changes of the external environment by Zhang Jie's work [36]. Chen Jin confirmed that mutual trust and sincere communication between enterprises and partners can improve the influence of absorptive capacity through a questionnaire survey [37].

In this paper, we suggest that absorption capacity will become particularly important to operating performance when openness is high, because a large amount of external technology will pour into the enterprise. At this point, the improvement of absorptive capacity can help the integration and transformation of the external technology, and then achieve the significant improvement of performance. So the following hypothesis is put forward in this paper:

H5: Openness is positively associated with relationship between absorption capacity and operating performance.

In social networks, the improvement of openness can strengthen the effect of enterprise's advantage, such as a certain competitive position and competition ability. He Yunbing confirmed that openness has a positive impact on the international competitiveness through empirical research for the lack of technology and resources can be acquired through more external channels [38]. Mitchell pointed out that the opening of enterprises is beneficial to transform and using of complementary knowledge [39]. Besides, Clark found that it is a good way to expand technological cooperation with parts suppliers to improve the performance in many aspects [40]. Chen Yufen believed that vertical or horizontal close cooperation with partners is conducive to the access to market information resources and technology resources, and gain a competitive advantage [41].

This paper suggests that: firstly, a wider range of external source of innovation cooperation means that more external partners and more innovation resources will be gained using enterprise's technology acquisition capability [42]; secondly, based on technology diffusion capability, the enterprise can strengthen its innovation affect and implant its innovative ideas to create a more favorable system environment; finally, deepening of cooperation with external sources can promote the circulation of knowledge resources, reduce the risk of trust and eventually gain benefits with the utilization of technology acquisition and diffusion capability. Therefore, this paper puts forward the following hypothesis:

H6: Openness is positively associated with relationship between technology acquisition and diffusion capability and operating performance.

Above all, Figure 1 shows the relational model assumed in this paper.

\section{Measures of Variables and Research Method}

\subsection{Measures of Variables}

\subsubsection{Independent Variable}

In this paper, innovation capability is seen as the independent variable. Usually, R\&D investment, R\&D staff quantity and other tangible resources can be used as indicators of the internal innovation capability [7]. Among these indicators, R\&D staff quantity (RDS) is a crucial role in innovation resources and the key to the transfor- 


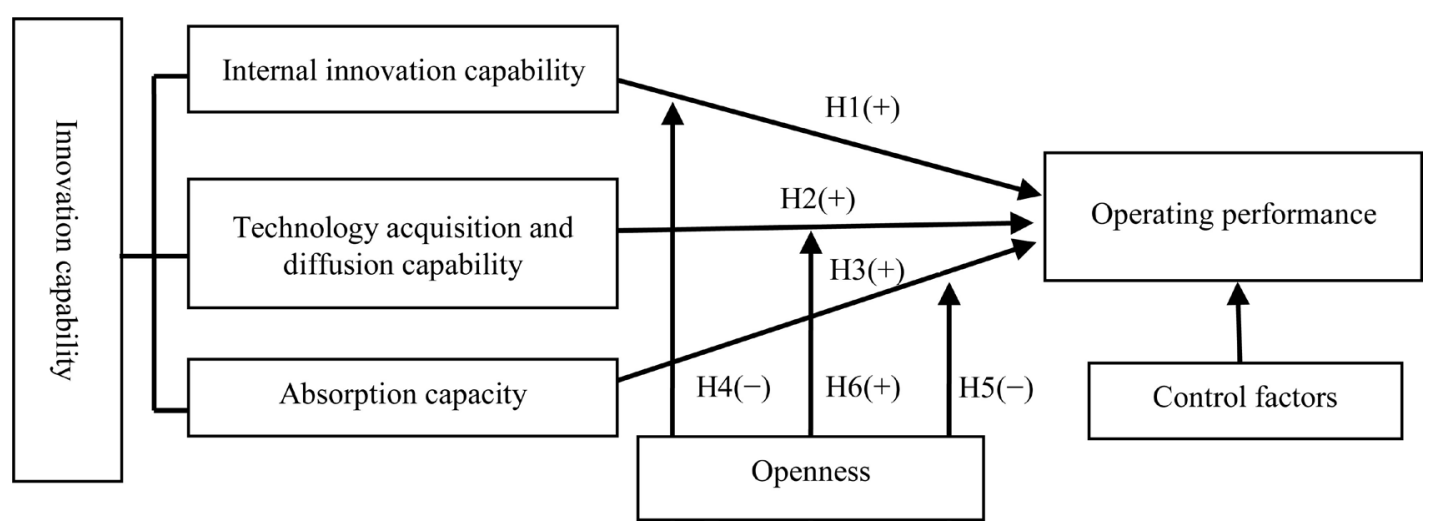

Figure 1. Conceptual model figure.

mation of input into the output. So this paper uses RDS as the indicator of internal innovation capability.

In social networks, the more close to the network center, the more influential the network nodes are [43]. Therefore, the relative competitive position in the network is the basis to acquire external knowledge resources and spread its own influence for the enterprise [44]. By applying social network theory to studies of innovation, scholars often use the gap with the technology leader or industry average to represent the capability of innovation and competition in the network. So we use the patents vector method to calculate the Euclidean distance (ED) between a single enterprises and lowermost level in industries to indicate the technology acquisition and diffusion capability:

$$
\mathrm{ED}_{i}=\sqrt{\sum_{k}\left(P_{i k}-P_{k}\right)^{2}}
$$

where $P_{i k}$ refers to the number of patents owned by enterprise $i$ in the classification $k$, and $P_{k}$ represents the lowest level in the industry. Technology distance calculated by patents is used to indicate acquisition and diffusion capability is available because patent data is more accurate to describe technology positioning, and it is easy to measure and compare [45]; meanwhile, technology distance is the intuitive and simple quantitative indicator to measure the relative competitiveness of enterprises.

Absorptive capacity is generally viewed as a kind of capability that is based on the internal knowledge accumulation. Therefore, the R\&D intensity, ratio of high-quality staff, the number of patents and publications often become the indicator of absorptive capacity. However, the identification and application of external knowledge is a long-term accumulation process, so the indicator should be continuous data instead of annual data. This paper uses knowledge stock (KS) generated by the long-term R\&D investment to characterize the absorptive capacity, which is more representative and persistent than the annual index. In addition, perpetual inventory method is used to calculate the stock of knowledge [46].

$$
\begin{aligned}
\mathrm{KS}_{i 0} & =\frac{R D C_{i 0}}{G_{i}+\theta} \\
\mathrm{KS}_{i t} & =(1-\theta) \times K S_{i(t-1)}+R D C_{i t}
\end{aligned}
$$

where the knowledge stock of enterprise $i$ at the end of year $t$ is represented as $\mathrm{KS}_{i t}$; R\&D investment of enterprise $i$ in the year of $t$ is represented as $\mathrm{RDC}_{i t}$; the depreciation rate is $\theta$, generally taken 20\% [47]; the average growth rate of enterprise $i$ during the study period is represented as $G_{i}$.

\subsubsection{Dependent Variable}

In this paper, the operating performance is the dependent variable. In the research of innovation management, performance is mainly defined as innovation performance, which is usually measured by the new product sales revenue, the amount of patent applications and so on. In this paper, the operating performance is appropriate to be represented by the pretax profit (EBIT) for three reasons: firstly, the realization of operating performance ultimately reflected in the improvement of economic benefits; secondly, financial performance indicator shows higher reliability and objectivity, and it is easy to make horizontal comparison and cost benefit analysis. 


\subsubsection{Moderator Variable}

In this paper, we take the innovation openness as the moderator variable. Most of the present literature defines openness mainly from two angles, that is, the extent of external resources and the extent of the cooperation with external organizations. As noted by Abdul-Hadi, open innovation of enterprises is mainly based on the inbound open innovation, while the outbound open innovation is not common [21]. Therefore, this paper uses the open degree of external resources input to represent openness, with the external technology investment proportion (EIR) as the indicator, and calculated by the following formula [48]:

$$
\mathrm{EIR}=\frac{\mathrm{PRI}+\mathrm{NPTI}+\mathrm{PTI}-\mathrm{IAI}}{\mathrm{PRI}+\mathrm{NPTI}+\mathrm{PTI}}
$$

where PRI represents increase of patent rights; NPRI represents increase of non-patent technology; PTI represents increase of proprietary technology; IAI represents increase in intangible assets produced by internal R\&D. Compared to other indicators, EIR has two major advantages: firstly, all calculations are available from financial statements with higher objectivity; secondly, this indicator reflects the degree of openness based on enterprise's long-term behavior, so it can rule out short-term opportunistic practice.

\subsubsection{Control Variables}

The industry enterprise belongs to will not only affect the operating and R\&D model, but also affect the average gross margin, thus affects the enterprise performance. So in this paper, we introduce the virtual variable IND, when the enterprise belongs to manufacturing industry, IND $=1$, when the enterprise belongs to the service industry, IND $=0$.

A large number of empirical studies show that enterprise size, financial leverage and corporate growth have a great influence on performance [49] [50]. So in this paper, the three factors are introduced as control variables to study the relationship, and characterized by the net value of fixed assets (FA), asset liability ratio (ALR) and revenue growth rate (RGR) respectively.

To sum up, there are four control variables, namely the industry, enterprise size, financial leverage, and corporate growth in this paper.

\subsection{Models}

In this paper, we use the method of multiple linear regressions to verify the relationship among the variables. In order to eliminate the variance of the models, the logarithm of the models is processed. The established models are as follows:

$$
\begin{aligned}
\mathrm{M} 1: \operatorname{In}(\mathrm{EBIT})= & \beta_{0}+\beta_{11} \operatorname{In}(\mathrm{FA})+\beta_{12} \mathrm{ALR}+\beta_{13} \mathrm{RGR}+\beta_{14} \mathrm{IND} \\
\mathrm{M} 2: \operatorname{In}(\mathrm{EBIT})= & \beta_{0}+\beta_{21} \operatorname{In}(\mathrm{RDS})+\beta_{22} \operatorname{In}(\mathrm{KS})+\beta_{23} \operatorname{In}(\mathrm{ED})+\beta_{24} \operatorname{In}(\mathrm{EIR}) \\
& +\beta_{\text {Control_Variable }} \\
\mathrm{M} 3: \operatorname{In}(\mathrm{EBIT})= & \beta_{0}+\beta_{21} \operatorname{In}(\mathrm{RDS})+\beta_{22} \operatorname{In}(\mathrm{KS})+\beta_{23} \operatorname{In}(\mathrm{ED})+\beta_{24} \operatorname{In}(\mathrm{EIR}) \\
& +\beta_{31} \operatorname{In}(\mathrm{EIR}) \times \operatorname{In}(\mathrm{RDS})+\beta_{32} \operatorname{In}(\mathrm{EIR}) \times \operatorname{In}(\mathrm{KS}) \\
& +\beta_{33} \operatorname{In}(\mathrm{EIR}) \times \operatorname{In}(\mathrm{ED})+\beta_{\text {Control_Variable }}
\end{aligned}
$$

Model 1 checks the relationship between control variables and operating performance; the independent variables are added to Model 2 to verify the hypothesis 1 to 3; then the cross terms of independent variables and moderating variable are added to Model 3 to check the moderation of openness and verify the hypothesis 4 to 6 .

\subsection{Research Sample}

In this paper, A-share enterprises in Shanghai and Shenzhen stock market are chosen as samples, and the study period is from January 1, 2011 to December 31, 2013. We also follow the following principles to select samples: 1) Only enterprises listed before December 31, 2010 and persistently operating until December 31, 2013 are selected. In order to eliminate the impact of accidental factors and the volatility of the enterprise's special circumstances, the equalization of the annual data is processed; 2) ST or *ST listed enterprises will be eliminated because of the abnormal financial situation; 3) Listing enterprises with incomplete information disclosure, in- 
complete basic financial data or the abnormal value of financial indicators will be excluded. Finally 137 listed enterprises meeting the above conditions form the research sample in this sample. Data are obtained mainly through Tai'an database, Chinese intellectual property network, Chinese and foreign patents database and financial statements of list enterprises.

\section{Empirical Results}

\subsection{Results}

First step, a correlation analysis with the SPSS16.0 software is processed, and the Pearson correlation coefficient between the main variables is shown in Table 1. As shown in the table, there is no significant correlation between the independent variables $(<0.45)$, indicating that the independent variable index is relatively independent, which means further regression model test is feasible. There is a significant correlation between independent variables and dependent variable. Among these, degree of relevance between R\&D staff quantity, knowledge stock and dependent variables is the highest, that is to say, internal innovation capability and absorptive capacity is vital to the enterprises. There is no significant correlation between the openness and the dependent variable which means openness can't affect the operating performance directly.

Second step, we use the method of multiple linear regression to analyze the sample data. In order to reduce the multicollinearity between the independent variables and the cross terms, the centralization of the independent variable and moderator variable is carried out in Model 3. Table 2 shows the regression results.

Table 1. The Pearson correlation coefficient matrix between the main variables.

\begin{tabular}{|c|c|c|c|c|c|c|c|c|}
\hline & EBIT & FA & ALR & RGR & RDS & KS & ED & EIR \\
\hline EBIT & 1 & & & & & & & \\
\hline FA & $0.636^{* * *}$ & 1 & & & & & & \\
\hline ALR & $0.184^{* *}$ & $0.313^{* * *}$ & 1 & & & & & \\
\hline RGR & -0.020 & -0.032 & -0.073 & 1 & & & & \\
\hline RDS & $0.650^{* * *}$ & $0.686^{* * *}$ & $0.159^{*}$ & -0.005 & 1 & & & \\
\hline KS & $0.448^{* * * *}$ & $0.391^{* * * *}$ & 0.055 & 0.072 & $0.443^{* * *}$ & 1 & & \\
\hline ED & $0.368^{* * *}$ & $0.232^{* * * *}$ & $0.167^{*}$ & $0.192^{* *}$ & $0.283^{* * *}$ & $0.340^{* * * *}$ & 1 & \\
\hline EIR & 0.032 & 0.134 & -0.004 & $0.144^{*}$ & 0.140 & $0.173^{* *}$ & -0.015 & 1 \\
\hline
\end{tabular}

Note: Significance level ${ }^{*} p<0.1,{ }^{* *} p<0.05,{ }^{* * *} p<0.01$.

Table 2. The Pearson correlation coefficient matrix between the main variables.

\begin{tabular}{|c|c|c|c|c|}
\hline & M1 & M2 & M3 & VIF value(M3) \\
\hline $\operatorname{Constant}\left(\beta_{0}\right)$ & $4.140^{* * * *}$ & $5.420^{* * *}$ & $10.664^{* * *}$ & \\
\hline $\mathrm{FA}\left(\beta_{11}\right)$ & $0.819^{* * *}$ & $0.468^{* * *}$ & $0.480^{* *}$ & \\
\hline $\operatorname{ALR}\left(\beta_{12}\right)$ & $-1.144^{*}$ & $-1.084^{* *}$ & $-1.206^{* *}$ & \\
\hline $\operatorname{RGR}\left(\beta_{13}\right)$ & 0.003 & -0.004 & & \\
\hline $\operatorname{IND}\left(\beta_{14}\right)$ & $-1.402^{* * * *}$ & $-1.270^{* * *}$ & $-1.058^{* * * *}$ & \\
\hline $\operatorname{RDS}\left(\beta_{21}\right)$ & & $0.334(0.110)^{* * *}$ & $0.042(0.172)$ & 6.407 \\
\hline $\mathrm{KS}\left(\beta_{22}\right)$ & & $0.176(0.089)^{* *}$ & $0.255(0.121)^{* *}$ & 5.172 \\
\hline $\operatorname{ED}\left(\beta_{23}\right)$ & & $0.069(0.043)$ & $0.166(0.057)^{* * *}$ & 2.224 \\
\hline $\operatorname{EIR}\left(\beta_{24}\right)$ & & $-0.021(0.064)$ & $-0.015(0.018)$ & 1.074 \\
\hline $\operatorname{EIR} * \operatorname{RDS}\left(\beta_{31}\right)$ & & & $-0.047(0.018)^{* * * *}$ & 5.522 \\
\hline $\mathrm{EIR}^{*} \mathrm{KS}\left(\beta_{32}\right)$ & & & $0.023(0.013)^{*}$ & 3.832 \\
\hline $\operatorname{EIR} * \operatorname{ED}\left(\beta_{33}\right)$ & & & $0.023(0.009)^{* *}$ & 2.203 \\
\hline$R^{2}$ & 0.492 & 0.612 & 0.659 & \\
\hline $\operatorname{Adj}-R^{2}$ & 0.475 & 0.586 & 0.629 & \\
\hline$F$-value & $29.783^{* * *}$ & $23.468^{* * * *}$ & $21.495^{* * *}$ & \\
\hline$R^{2}$ increment & & 0.12 & 0.047 & \\
\hline
\end{tabular}

Note: Significance level ${ }^{*} p<0.1,{ }^{* *} p<0.05,{ }^{* * *} p<0.01$, values in parentheses are standard deviation. 
From the regression results in Table 2, we can see that:

1) After adding the independent variables and adjustment variables to model $2, R^{2}$ value increases from 0.475 to 0.586 and $F$ value reaches the significance level of 0.01 , which shows that the fitting degree of equations is fair. In model 3, $R^{2}$ value increases from 0.586 to 0.629 and $F$ value reaches 0.01 level, which means the fitting degree of equations is further increased. In addition, the VIF values of all the variables in model 3 are less than 10 , so it passes the multicollinearity test.

2) The empirical results show that the value of $\beta$ between the R\&D staff quantity and dependent variable is 0.334 , and the value of $\beta$ between the knowledge stock and dependent variable is 0.176 , all the values reach a significant level of 0.05 . It shows that the increase of $R \& D$ staff quantity and knowledge stock can significantly improve the performance. Therefore, the hypothesis 1 and 3 are confirmed. The $\beta$ value between the technological distance and the dependent variable is 0.069 and it is not significant, which means that the technology acquisition and diffusion capability have little effect on operating performance, so the hypothesis 2 can't be confirmed.

(3) The empirical results of model 3 show that $\beta_{31}$ value is -0.047 , and the significant level is 0.01 . At the same time, the direct effect of R\&D staff quantity on dependent variable is no longer significant after adding this cross term, so the hypothesis 4 is confirmed. Further, the difference between two kinds of enterprises which have a higher or lower openness is tested by using the method proposed by Aiken, as shown in Figure 2(a): $R \& D$ staff quantity of enterprises whose openness above average has a smaller degree of effect on performance than whose openness below average, which shows that the openness has a negative effect on the relationship between the internal innovation capability and operating performance.

4) The empirical results of model 3 show that $\beta_{32}$ value is 0.023 , and the significant level is 0.1 . Meanwhile, the $\beta$ value between knowledge stock and dependent variable increases from 0.176 to 0.255 after adding this cross term, which indicates that the positive effect is enhanced, so that the hypothesis 5 is confirmed. As shown in Figure 2(b), regulation direction test shows that knowledge stock of enterprises whose openness is above average has a higher degree of effect on the performance. On the contrary, increase of knowledge stock of sample enterprises whose openness is below the average leads to performance reduction instead, which shows that the benefits from external technology absorption and transformation is not enough to compensate for the cost of input to the absorptive capacity, namely the investment to absorption capability cannot make ends meet. So openness has a positive effect on the relationship between absorption capability and operating performance.

5) The empirical results of model 6 show that $\beta_{33}$ value is 0.023 , and the significant level is 0.05 . After adding the cross term, $\beta$ value between technical distance and dependent variable is 0.166 and the significant level is 0.01 , which confirms the hypothesis 6 for the positive effect of technology distance on the dependent variable is enhanced under the effect of openness. In the same way, as shown in Figure 2(c), the slope between technical distance and performance of the enterprises whose openness is above average is significantly greater than those below the average, which shows that openness has a positive effect on the relationship between technology acquisition and diffusion capability and operating performance.

\subsection{Discussion}

In this paper, the hierarchical multiple regression analysis of the data from sample enterprises reveals that: in-

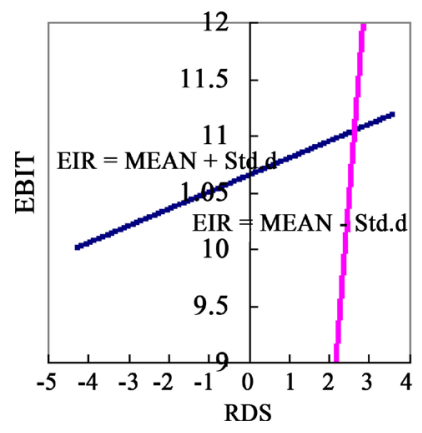

(a)

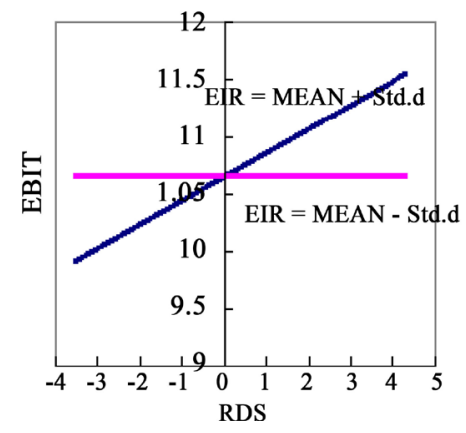

(b)

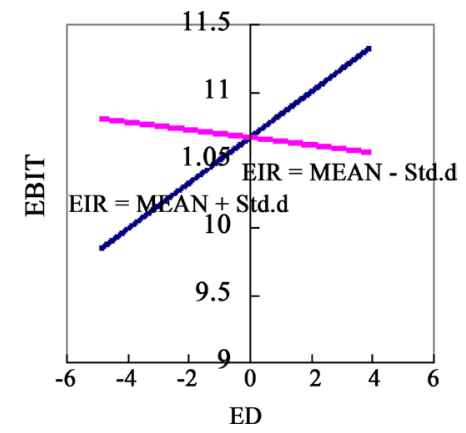

(c)

Figure 2. Regulation direction tests of openness. 
ternal innovation capability and absorptive capacity have a significant positive impact on operating performance. However, the effect of technology acquisition and diffusion capability on performance is not significant. What's more, under the regulation of openness, positive effect of technology acquisition and diffusion capability and absorptive capacity on operational performance is significantly enhanced, but the positive effect of internal innovation ability is weakened, specifically.

As a driving force of growth, internal innovation capabilities is the most important factor for performance and it even determines whether the enterprise can gain an advantage and realize the profit in the fierce competition environment. On the other hand, absorptive capacity also has an important impact on the operating performance to a certain extent for its Importance of identifying, digesting, transforming and applying external technology and knowledge. The effect of technology acquisition and diffusion capability on performance isn't proved. There may be two reasons for this result: one is "external factors always need to play a role through internal factors", technology acquisition and diffusion only affect the operating performance indirectly. The second one is the enterprise cannot get the most out of this kind of capability if the openness is not high enough, so too much investment to this capability may not get equal benefits. This result is consistent with the conclusion that the effect of internal R\&D on perform is larger than external open innovation proposed by Kafouros and the view of "indirect theory" proposed by Tsai and other scholars [35] [19].

Actually, benefits will be gained if the enterprises change from completely independent internal R\&D to open innovation for a certain extent. It is the most obvious that the positive impact of technology acquisition and diffusion on operating performance will be greatly enhanced. When the breadth and depth of opening improves, the possibility of obtaining helpful innovation resources from outside and short-term financial benefits by using external technology knowledge rapidly and efficiently is greatly increased. At the same time, knowledge diffusion capacity can also be used to expand its influence in the industry, which will lead to a long-term benefit. The similar conclusion is reached by Stephen Roper's study in Ireland growth enterprise market. He noted that the external effect of open innovation is more influenced by the actual opening density and width of the enterprises [51].

However, improvement of openness may also produce some negative effects, it is the most obvious that the positive impact of internal innovation capability on operating performance will be greatly weakened. It is possible to reduce the internal R\&D output efficiency and lead enterprises to neglect internal innovation capability in order to pursue short-term benefits. Because of the strong force of internal innovation, enterprises cannot blindly expand the openness at the expense of the internal innovation capability.

In addition, the improvement of openness also requires enterprises to have the corresponding absorption capacity, because it is becoming increasingly important with the openness to be improved. In the face of complex and different external technology and partners, enterprises should be able to identify, transform, digest and apply the external knowledge. When the two cannot match, enterprises can reduce openness and put more resources into the improvement of internal innovation capability instead, so as to absorb the external technology in their acceptable range; or put more resources to improve absorptive capacity to match the requirement.

\section{Significance and Limitations}

In this paper, the research has the following theoretical significance: firstly, we choose openness as a moderating variable to study its regulation effect. It is a new perspective of researches on open innovation performance; secondly, this paper confirms that open innovation has a two-sided effect on enterprises performance. Open innovation has been considered to be an effective model of innovation, but this study finds the effect on the performance has two sides, and analyzes the regulation direction of openness on different types of capability.

The practical significance of this paper is that enterprises should choose appropriate open innovation strategy based on their own capability in the open environment. According to capability level, enterprises are divided into four types in this paper, as shown in Figure 3, and open innovation strategy is put forward as follows: comprehensive opening strategy is available for the enterprises with strong internal innovation capability and strong technology acquisition and diffusion capability. The opening width should be focused on instead of opening depth, so as to take advantage of internal and external resources; enterprises with strong internal innovation capability but weak technology acquisition and diffusion capability should rely more on its own advantage, and choose the relatively conservative open strategy, namely open in some areas to maximize the positive effect of internal innovation on performance; it is a good choice for an enterprise with weak internal innovation capabili- 


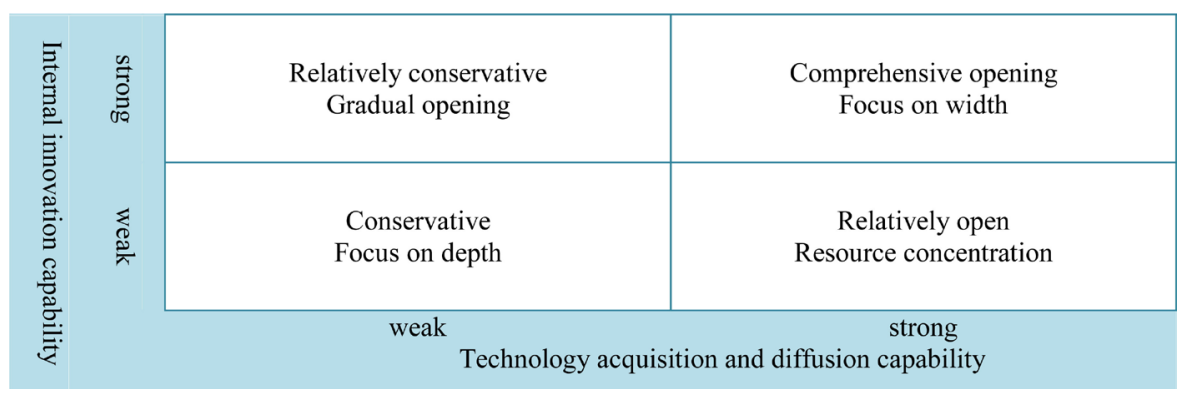

Figure 3. Open innovation strategy for different enterprises.

ty and strong technology acquisition and diffusion capability to take relatively open strategy within the range that its absorptive capacity can accept, so as to make more use of external knowledge and technology to create economic benefits. Meanwhile, because of the weak internal innovation capability, the enterprise should put more resources to key technology and projects. If two kinds of capability are both weak, the enterprises should choose to focus on internal innovation, because the effect of internal innovation capability on the performance is more important in this circumstances. Enterprises can focus on the opening depth to make most of limited resources.

To sum up, this paper studies the influence of innovation capability on operating performance under the moderation of openness, not only obtains that the internal innovation capability has a greater impact on performance, but also explains why opening has a two-sided effect on performance from a new angle. Moderate openness can bring benefits to enterprises mainly because it improves technology acquisition and diffusion capability's positive influence, but its hidden trouble is mainly reflected on the sensitivity reduce of performance to internal innovation. So open innovation needs to be consistent with enterprises' own capabilities, especially absorption capability, and enterprises on different states of capabilities should adopt different open innovation strategies.

This paper has the following limitations: firstly, the operating performance is represented by financial data, so innovation performance, growth performance can be researched in the future; secondly, sample enterprises can be further divided, and research on appropriate openness for each kind of enterprises is the future direction of improvement.

\section{Funding}

Funded by Aeronautical Science Fund "research on cross-business coordinated development mechanism of aviation industry enterprises" (2013ZG52077) and the key project of Social Science Fund of Jiangsu Province "research on open innovation behaviors and decision-making mechanism of enterprises under the network environment" (15GLA001).

\section{References}

[1] Spithoven, A., Clarysse, B. and Knockaert, M. (2009) Building Absorptive Capacity to Organise Inbound Open Innovation in Traditional Industries. Technovation, 311, 10-21.

[2] Ye, J. and Kankanhalli, A. (2013) Exploring Innovation through Open Networks: A Review and Initial Research Questions. IIMB Management Review, 2, 69-82.

[3] Chesbrough, H. (2003) Open Innovation: The New Imperative for Creating and Profiting, from Technology. Harvard Business School Press, Boston.

[4] Chen, Y.F. and Chen, J. (2009) A Study on the Mechanism of Open Innovation Promoting Innovative Performance. Science Research Management, 4, 1-9+28.

[5] Kyläheiko, K., Jantunen, A., Puumalainen, K., Saarenketo, S. and Tuppura, A. (2010) Innovation and Internationalization as Growth Strategies: The Role of Technological Capabilities and Appropriability. International Business Review, 205, 508-520.

[6] Li, P., Chen, H.H. and Liu, Y.M. (2014) An Empirical Study on Innovation Openness under the Open Innovation Model. Forum on Science and Technology in China, 1, 10-15.

[7] Yeşil, S., Koska, A. and Büyükbeşe, T. (2013) Knowledge Sharing Process, Innovation Capability and Innovation Performance: An Empirical Study. Procedia-Social and Behavioral Sciences, 75, 217-225. 
[8] Yun, J., Ma, W.J. and Chen, L. (2012) The Interaction Effect of Openness and Network Capability on Innovation Performance. Science Research Management, 7, 8-15.

[9] Gu, X.M. and Ren, A.L. (2011) Research on the Impact on Innovation Performance by Enterprise's Learning Capacity and Open Innovation Interaction. Science \& Technology Progress and Policy, 12, 79-82.

[10] Wallin, M.W. and Von Krogh, G. (2010) Organizing for Open Innovation: Focus on the Integration of Knowledge. Organizational Dynamics, 39, 145-154. http://dx.doi.org/10.1016/j.orgdyn.2010.01.010

[11] Hagedorm, J. and Wang, N. (2012) Is There Complementarity or Substitutability between Internal and External R\&D Strategies? Research Policy, 41, 1072-1083. http://dx.doi.org/10.1016/j.respol.2012.02.012

[12] Wei, Y.C. and Li, K. (2010) Empirical Analysis on Development Trend and Determinants of International Competitiveness in China Manufacturing. Journal of International Trade, 3, 99-104.

[13] He, J.H. and He, C.Z. (2012) Research on the Impact on Technological Capacity and Innovation Strategy on Innovation Performance. Soft Science, 8, 113-117.

[14] Li, Q.W. (2011) The Research on the Impact of High-Tech Entrepreneurial Innovative Capability on Business Performance. Master's Thesis, Anhui University, Hefei.

[15] Wang, T.N. and Tu, Y.M. (2012) Influence of Technology Innovation Capacity on Enterprise’s Performance under Regulation of Management Innovation Capacity. Technology Economics, 10, 25-32.

[16] Mao, W.Q., Chen, J. and Yu, L.J. (2012) Research on the Evaluation Index System of Product and Technology Innovation Capability. Science \& Technology Progress and Policy, 9, 113-117.

[17] Tsai, K.-H. and Wang, J.-C. (2007) External Technology Acquisition and Firm Performance: A Longitudinal Study. Journal of Business Venturing, 23, 91-112. http://dx.doi.org/10.1016/j.jbusvent.2005.07.002

[18] Zhang, C.J. and Wei, L. (2007) Research on Internationalization Management Path of Technology Output Oriented Private Small and Medium-Sized Enterprise. Practice in Foreign Economic Relations and Trade, 1, 25-28.

[19] Zhao, W.H. and Liang, Q.Z. (2010) The Study between Technology Acquisition Mode and Firm Performance. Studies in Science of Science, 5, 741-746+776.

[20] Janeiro, P., Proença, I. and Gonçalves, V. da C. (2013) Open Innovation: Factors Explaining Universities as Service Firm Innovation Sources. Journal of Business Research, 66, 2017-2023. http://dx.doi.org/10.1016/j.jbusres.2013.02.027

[21] Abulrub, A.H.G. and Lee, J. (2012) Open Innovation Management: Challenges and Prospects. Procedia-Social and Behavioral Sciences, 41, 130-138. http://dx.doi.org/10.1016/j.sbspro.2012.04.017

[22] Sui, M.Q. and Li, Y. (2012) An Empirical Study on Factors of Diffusion Performance of New Energy Vehicle Technology under Clustering Perspective. Journal of Systems \& Management, 5, 710-715.

[23] Therrien, P., Doloreux, D. and Chamberlin, T. (2011) Innovation Novelty and (Commercial) Performance in the Service Sector: A Canadian Firm-Level Analysis. Technovation, 31, 655-665. http://dx.doi.org/10.1016/j.technovation.2011.07.007

[24] Tsai, K.H., Hsieh, M.-H. and Hultink, E.J. (2011) External Technology Acquisition and Product Innovativeness: The Moderating Roles of R\&D Investment and Configurational Context. Journal of Engineering and Technology Management, 28, 184-200. http://dx.doi.org/10.1016/j.jengtecman.2011.03.005

[25] Tang, Y.H. and Wang, S.F. (2012) Research of Network Implant’s Influence on Enterprise. Special Zone Economy, 10, 273-275.

[26] Wang, Z.W. and Chen, J. (2012) Empirical Research on Dimension Vision and Measurement of Absorptive Capacity. Technology Economics, 9, 7-11.

[27] Alexander, S., Paul-Georg, G., Henning, T. and Oliver, G. (2013) Models for Open Innovation in the Pharmaceutical Industry. Drug Discovery Today, 18, 1133-1137. http://dx.doi.org/10.1016/j.drudis.2013.07.013

[28] Ren, A.L. (2011) Research on Relationship between Learning Ability and Open Enterprise Innovation Performances. Statistics \& Decision, 14, 182-184.

[29] Hong, R.Y. (2012) The Synergistic Effect of Relationship Embedding and Absorptive Capacity on Enterprise Knowledge Search-Analysis on the Independent Innovation of Chinese Car Enterprises in the Global Manufacturing Network. Journal of Chongqing University (Social Science Edition), 1, 71-76.

[30] Tim, E., Riek, D. and Max, M. (2005) Understanding Innovation in Small and Medium-Sized Enterprises: A Process Manifest. Technovation, 25, 1119-1127. http://dx.doi.org/10.1016/j.technovation.2004.04.005

[31] Kim, H. and Park, Y. (2010) The Effects of Open Innovation Activity on Performance of SMEs: The Case of Korea. International Journal of Technology Management, 52, 236-256.

[32] Rosenbusch, N., Brinkmann, J. and Bausch, A. (2011) Is Innovation Always Beneficial? A Meta-Analysis of the Rela- 
tionship between Innovation and Performance in SMEs. Journal of Business Venturing, 26, 441-457. http://dx.doi.org/10.1016/j.jbusvent.2009.12.002

[33] Kafouros, M.I. and Forsans, N. (2012) The Role of Open Innovation in Emerging Economies: Do Enterprises Profit from the Scientific Knowledge of Others? Journal of World Business, 47, 362-370. http://dx.doi.org/10.1016/j.jwb.2011.05.004

[34] Westergren, U.H. and Holmström, J. (2012) Exploring Preconditions for Open Innovation: Value Networks in Industrial Firms. Information and Organization, 22, 209-226. http://dx.doi.org/10.1016/j.infoandorg.2012.05.001

[35] Li, Z. and Yang, H.T. (2012) The Impact of Absorptive Capacity, Relationship Learning and Knowledge Integration on the Enterprise Innovation Performance. Science Research Management, 1, 79-89.

[36] Zhang, J., Qi, A.B. and Xiong, Q.Q. (2012) The Antecedents, Absorptive Capacity and Innovation Performance: Empirical Research on the Mediating Effect of Absorptive Capacity. Science of Science and Management of S\&T, 5, 2937.

[37] Chen, J., Jiang, Z.J. and Chen, Y.F. (2011) The Influencing Factors of Absorptive Capacity under the Paradigm of Open Innovation. Journal of Zhejiang University (Humanities and Social Sciences), 5, 71-82.

[38] He, Y.B. and Zeng, Y. (2013) How Open \& Indigenous Innovation Affects Industries International Competitiveness: An Empirical Study on Chinese Manufacturing Industries Based on the Panel Data from the Year 2000 to 2010. Science of Science and Management of S\&T, 3, 13-22.

[39] Mitchell, W. and Singh, K. (1992) Incumbents' Use of Pre-Entry Alliances before Expansion into New Technical SubFields of an Industry. Journal of Economic Behavior and Organization, 18, 347-372. http://dx.doi.org/10.1016/0167-2681(92)90015-4

[40] Clark, K.B. (1989) Project Scope and Project Performance: The Effect of Parts Strategy and Supplier Involvement on Product Development. Management Science, 35, 1247-1263. http://dx.doi.org/10.1287/mnsc.35.10.1247

[41] Chen, Y.F. and Chen, J. (2009) A Study on the Mechanism of Open Innovation Promoting Innovative Performance. Science Research Management, 4, 1-9+28.

[42] Laursen, K. and Salter, A. (2006) Open for Innovation: The Role of Openness in Explaining Innovation Performance among UK Manufacturing Firms. Strategic Management Journal, 27, 131-150. http://dx.doi.org/10.1002/smj.507

[43] Su, H.-N. and Lee, P.-C. (2012) Framing the Structure of Global Open Innovation Research. Journal of Informetrics, 6 , 202-216. http://dx.doi.org/10.1016/j.joi.2011.12.001

[44] Ni, Z.Y. and Liu, Q. (2013) Research on the Enterprise Technology Innovation Capacity under the New Model of Open Innovation. Soft Science, 10, 59-63.

[45] Bar, T. and Leiponen, A. (2012) A Measure of Technological Distance. Economics Letters, 116, 457-459. http://dx.doi.org/10.1016/j.econlet.2012.04.030

[46] Chen, J., Liang, L. and Wu, H. (2013) Industrial Agglomeration and Innovation Performance under the Background of Open Innovation: Evidence from Chinese High-Tech Industries. Studies in Science of Science, 4, 623-629+577.

[47] Yang, J.W. (2007) Research on Technological Innovation Capability of Open Innovation Model. The Theory and Practice of Finance and Economics, 2, 98-102.

[48] Wang, W.-H., Zhang, Z. and Huang, Q. (2015) The Dual Effects of External Technology on Firm Performance-An Empirical Research of Nonlinear Perspective. Collected Essays on Finance and Economics, 1, 84-91.

[49] Raghuram, R. and Luigi, Z. (2004) Making Capitalism Work for Everyone. Journal of Applied Corporate Finance, 16, 101-108. http://dx.doi.org/10.1111/j.1745-6622.2004.tb00677.x

[50] La Porta, R., Lopez-de-silanes, F., Shleifer, A. and Vishny, R. (2002) Investor Protection and Corporate Valuation. Journal of Finance, 57, 1147-1170. http://dx.doi.org/10.1111/1540-6261.00457

[51] Roper, S., Vahter, P. and Love, J.H. (2013) Externalities of Openness in Innovation. Research Policy, 42, $1544-1554$. http://dx.doi.org/10.1016/j.respol.2013.05.006 